\title{
Evaluation of Antitranspirants for Enhancing Temporary Water Stress Tolerance in Bedding Plants
}

\author{
Suejin Park, Sarah A. Mills, Youyoun Moon, \\ and Nicole L. Waterland ${ }^{1}$
}

AdDitional INDEX wORDs. abscisic acid, $\beta$-pinene polymer, wilt status, shelf life extension, stomatal conductance, postproduction

SUMMARY. Water stress during shipping and retailing reduces the postproduction quality and marketability of bedding plants. Antitranspirants can temporarily prevent plants from wilting by either physically blocking stomata or physiologically inducing stomatal closure, limiting transpirational water loss from leaves. The goal of this research was to evaluate the efficacy of commercially available antitranspirants on enhancing temporary water stress tolerance in bedding plants. Two physical antitranspirants $[\beta$-pinene polymer $(\beta P)$ and vinyl-acrylic polymer (VP)], and three physiological antitranspirants [two sugar alcoholbased compounds (SACs) and a biologically active form of abscisic acid (s-ABA) ] were applied to begonia (Begonia semperflorens-cultorum), new guinea impatiens (Impatiens hawkeri), impatiens (Impatiens walleriana), petunia (Petunia $\times$ bybrida), african marigold (Tagetes evecta), and french marigold (Tagetes patula). Physical antitranspirants were sprayed on foliage and physiological antitranspirants were drenched to the media. All antitranspirants were applied at half $(0.5 \times)$, equal to $(1 \times)$, or twice $(2 \times)$ the manufacturer's recommended rate. Extended shelf life was observed when $\beta P$ or s-ABA was applied. Treatment with $\beta P$ increased the shelf life of impatiens and african marigold by 1 and 1.3 days compared with control plants, respectively. The application of $\beta P$ at $2 \times$ was more effective at delaying visual wilting than at lower rates $(0.5 \times$ and $1 \times)$ in african marigold. Applications of s-ABA delayed wilting by 1.3 to 3.7 days in all tested cultivars. The shelf lives of impatiens and petunia treated with s-ABA at $2 \times$ were extended the most by 3.7 and 3.0 days compared with control plants, respectively. A rapid reduction of stomatal conductance $\left(g_{s}\right)$ was observed within 4 hours of $\beta P$ or s-ABA application in plants showing delayed wilting symptoms. s-ABA treatment appeared to cause marginal leaf chlorosis in impatiens, whereas application of $\beta P$ damaged the opened flowers in all tested cultivars. The application of VP or SACs did not extend shelf life in any treated plants. These results suggest that foliar application of $\beta P$ on selected species and treatment with $s-A B A$ on most of species would allow bedding plants to withstand water deficit during shipping and/or retailing.

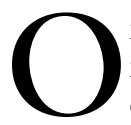
rnamental bedding plants represent the largest sector of the floriculture industry in the Unites States and have a wholesale

Division of Plant and Soil Sciences, West Virginia University, Morgantown, WV 26506

Salaries and research support were provided in part by State and Federal funds appropriated to the West Virginia Agricultural and Forestry Experiment Station, West Virginia University. Scientific Article No. 3271 of the West Virginia Agricultural and Forestry Experiment Station, Morgantown.

We thank Green Circle Growers Inc., PanAmerican Seed, and Syngenta Flowers for their donation of plant material.

The information in this publication is for educational purposes only. Mention of a trademark, proprietary product, or vendor does not constitute a guarantee or warranty of the product, nor does it imply approval or disapproval to the exclusion of other products or vendors that may also be suitable.

${ }^{1}$ Corresponding author. E-mail: nicole.waterland@ mail.wvu.edu. value of $\$ 1.96$ billion accounting for $45 \%$ of all floriculture crops (U.S. Department of Agriculture, 2014). In the last decade, there has been a shift in the retailing of ornamental crops. Customers tend to purchase bedding plants more in mass market retailers or superstores and general retail outlets (such as supermarkets) than in traditional garden centers and florists because of convenience and lower prices (Yue and Behe, 2008). In addition, the major growers have moved their production into areas characterized by lower labor cost and more favorable climate conditions to reduce the cultivation cost (Ferrante et al., 2015). As a result, the location of crop production could be further away from markets, forcing plants to spend an extended period of time without proper irrigation during shipping and/or retailing (Waterland et al., 2010a; Weaver and van Iersel, 2014). Additionally, during postproduction periods, plants are often exposed to adverse environmental conditions, including high temperatures and inadequate irrigation, which accelerate substrate drying and plant wilting. Crop losses caused by these poor postproduction conditions are estimated to result in $5 \%$ to $20 \%$ of unsalable crops (Healy, 2009), and water stress is one of the major causes of diminished aesthetic quality and salability of plants. Therefore, it is highly desired to minimize crop damage caused by water deficit to maintain high quality and prolong longevity of bedding plants during postproduction.

Water stress causes plants to synthesize a phytohormone called abscisic acid (ABA) in the root system, and it is translocated to leaves through the transpiration stream (Taiz and Zeiger, 2010). When ABA reaches guard cells, it binds to $A B A$ receptors that activate an ion efflux, which reduces turgor pressure in the guard cells. Due to loss of turgidity, the guard cells become flaccid and stomata are closed. Closing of stomata inhibits transpiration and allows the plant to withstand water stress by decreasing water loss. Using this principle, growers can utilize antitranspirants to reduce transpiration, thereby limiting water loss during shipping and retailing (Iriti et al., 2009; Odlum and Colombo, 2007; Waterland et al., 2010b).

\begin{tabular}{llll}
\hline $\begin{array}{l}\text { Units } \\
\text { To convert U.S. to SI, } \\
\text { multiply by }\end{array}$ & U.S. unit & SI unit & $\begin{array}{l}\text { To convert SI to U.S., } \\
\text { multiply by }\end{array}$ \\
\hline 29.5735 & $\mathrm{fl} \mathrm{oz}$ & $\mathrm{mL}$ & 0.0338 \\
2.54 & inch $(\mathrm{es})$ & $\mathrm{cm}$ & 0.3937 \\
1 & $\mathrm{ppm}$ & $\mathrm{mg} \cdot \mathrm{L}^{-1}$ & 1 \\
0.001 & $\mathrm{ppm}$ & $\mathrm{mL} \cdot \mathrm{L}^{-1}$ & 1,000 \\
10.7639 & $\mathrm{~W} / \mathrm{ft}^{2}$ & $\mathrm{~W} \cdot \mathrm{m}^{-2}$ & 0.0929 \\
$\left({ }^{\circ} \mathrm{F}-32\right) \div 1.8$ & ${ }^{\circ} \mathrm{F}$ & ${ }^{\circ} \mathrm{C}$ & $\left({ }^{\circ} \mathrm{C} \times 1.8\right)+32$
\end{tabular}


Antitranspirants are chemical compounds that increase water stress tolerance by preventing transpirational water loss in plants. Based on their mode of action, antitranspirants can be classified into two major groups, physical and physiological antitranspirants (Anderson and Kreith, 1978; Shinohara and Leskovar, 2014; Waterland et al., 2010b). Physical antitranspirants contain waxes, resins, latexes, or polymers that coat the leaf surface and minimize water loss from the plant by blocking stomata (Goreta et al., 2007). Such physical antitranspirants have shown positive effects on water stress tolerance in pepper [Capsicum annuum (del Amor et al., 2010)], peach tree [Prunus persica (Steinberg et al., 1990)], and herbaceous plants (Anderson and Kreith, 1978). Physiological antitranspirants minimize transpiration by inducing plants to close stomata. These compounds may contain $\mathrm{ABA}$ or other chemicals that increase the $\mathrm{ABA}$ concentration in plants (Waterland et al., 2010b). Exogenous application of ABA has enhanced water stress tolerance in various horticultural crops (Agehara and Leskovar, 2012; Astacio and van Iersel, 2011; Goreta et al., 2007; Shinohara and Leskovar, 2014). Goreta et al. (2007) found that foliar application of ABA enhanced water deficit tolerance of pepper, which was attributed to decreased $g_{s}$ and increased leaf water potential. Overall, antitranspirants have been shown to reduce wilting caused by water stress. However, some studies have demonstrated that plant responses to antitranspirants vary depending on species, concentrations of antitranspirants applied, developmental stages, and growing environmental conditions (Blanchard et al., 2007; Dunn et al., 2012; Shinohara and Leskovar, 2014; Waterland et al., 2010a).

Antitranspirants have been used to help plants withstand stress caused by water deficit, and many studies have focused on fruits, vegetables, turf, field crops, and woody plants. Little research has been conducted on the effect of antitranspirants on the postproduction quality of bedding plants. Furthermore, most research has evaluated individual antitranspirant and an efficacy comparison study among different products of physical and physiological antitranspirants is lacking. The physical antitranspirants in this study contained either $\beta$-P or VP as a coating agent and the physiological antitranspirants were two sugar alcohol-based compounds (SACl and SAC2), which are supposed to increase the concentration of ABA in plants, and s-ABA. SACl contains xylitol, and SAC2 contains polyhydric alcohol and extracts from seaweed [e.g., red algae (Gracilaria sp.)], corn (Zea mays), and berries [e.g., brambles (Rubus sp.), blueberry (Vaccinium sp.), strawberry (Fragaria xananassa)]. The goal of this research was to evaluate the efficacy of these commercially available antitranspirants on enhancing water stress tolerance in bedding plants.

\section{Materials and methods}

EXPT. 1: SHELF LIFE OF ANTITRANSPIRANT-TREATED BEDDING PLANTS. Eight cultivars of six popular bedding plant species were selected in this experiment. Four-week-old seedlings of 'Bada Bing Rose' begonia, 'Harmony Spicy Peach' new guinea impatiens, 'Double Fiesta Ole Purple Stripe' impatiens, 'Madness Double Red' and 'Wave Pink' petunia, 'Antigua Yellow' and 'Taishan Orange' african marigold, and 'Bonanza Yellow' french marigold were obtained in 288-plug trays except for impatiens and new guinea impatiens (72-plug tray) from Green Circle Growers Inc. (Oberlin, $\mathrm{OH})$. All plants were transplanted into 4 -inch pots with soilless greenhouse media (Sunshine ${ }^{\circledR}$ Mix \#1; Sun Gro Horticulture, Agawam, MA) in Apr. 2013. They were grown in the greenhouse (Morgantown, WV) under natural irradiance with supplemental lighting. High-pressure sodium lamps (600W HS200 deep reflector; Hortilux, Pijnacker, The Netherlands) were used for supplemental lighting when natural radiance fell below $50 \mathrm{~W} \cdot \mathrm{m}^{-2}$. The average photosynthetic photon flux density (PPFD) was $412 \mu \mathrm{mol} \cdot \mathrm{m}^{-2} \cdot \mathrm{s}^{-1}$ from 0630 to 2030 HR daily [mean daily light integral $\left.(\mathrm{DLI})=20.8 \mathrm{~mol} \cdot \mathrm{m}^{-2} \cdot \mathrm{d}^{-1}\right]$. Mean greenhouse temperatures were $23.1 / 19.6 \pm 2.9 / 2.3^{\circ} \mathrm{C}$ day $/$ night (mean $\pm \mathrm{SD}$ ) with daytime relative humidity of $76.3 \% \pm 13.7 \%$. Plants were fertilized with $15 \mathrm{~N}-2.2 \mathrm{P}-$ 12.5K (Peter ${ }^{\circledR}$ Excel Cal-Mag; Everris
$\mathrm{NA}$, Marysville, $\mathrm{OH}$ ) at $200 \mathrm{mg} \cdot \mathrm{L}^{-1}$ nitrogen $(\mathrm{N})$. This was reduced to $100 \mathrm{mg} \cdot \mathrm{L}^{-1} \mathrm{~N}$ one week before treatment.

All bedding plants were treated with antitranspirants when they reached a marketable stage of at least one open flower per plant. Begonia, new guinea impatiens, and impatiens were treated in June 2013, and marigold and petunia were treated in July 2013. Plants were irrigated with deionized (DI) water to container capacity $12 \mathrm{~h}$ before treatment. Physical antitranspirants were sprayed on the top and the underside of the plant canopy (about $35 \mathrm{~mL}$ per plant) with a pressurized sprayer (Regulator Bak-Pak; H.D. Hudson, Chicago, IL), and physiological antitranspirants were drenched in substrates $(60 \mathrm{~mL}$ per pot). Control treatments for physical and physiological antitranspirant applications were sprayed and drenched with DI water, respectively, and then they were irrigated daily with $100 \mathrm{mg} \cdot \mathrm{L}^{-1}$ $\mathrm{N}$ (irrigated control) or water was withheld (water-stressed control) during the period of the experiment. The physical antitranspirants used were $\beta P$ (Wilt-Pruf ${ }^{\circledR}$; Wilt-Pruf Products, Essex, CT) and VP (Moisturin; WellPlant, Sparks, NV). The physiological antitranspirants used were SACl (Stasis $^{\text {TM }}$; Natural Industries, Houston, TX), SAC2 (RootZone $^{\mathrm{Tm}}$; GSI Horticultural, Bend, OR), and s-ABA (ConTego ${ }^{\text {TM }}$, VBC30101 , Valent BioSciences, Libertyville, IL). All antitranspirants were applied at either half $(0.5 \times)$, equal to $(1 \times)$, or twice $(2 \times)$ the manufacturer's recommended application rate (Table 1 ). Plants were held in the greenhouse under the previously described environmental conditions for subsequent evaluations. Half of plants treated with each antitranspirant had water withheld (waterstressed) until all treated plants reached a visual wilt status rating of 3 or below (unmarketable) as described by Waterland et al. (2010c). Wilt status ratings were from 1 to 5 with $5=$ completely turgid, $4=$ soft to the touch but still upright, $3=$ starting to wilt, 2 = severely wilted, and $\mathrm{l}=$ wilted to the point that leaves are dried and desiccated (Waterland et al., 2010a). The other half were irrigated daily with $100 \mathrm{mg} \cdot \mathrm{L}^{-1} \mathrm{~N}$ (irrigated daily) to 
Table 1. Manufacturer's recommended application rate of antitranspirants.

\begin{tabular}{lc}
\hline Antitranspirant $^{\mathbf{z}}$ & Rate $^{\left(\mathbf{m L} \cdot \mathbf{L}^{-\mathbf{l}}\right)^{\mathbf{y}}}$ \\
\hline$\beta P$ & 100.0 \\
VP & 100.0 \\
SAC1 & 50.0 \\
SAC2 & 7.8 \\
s-ABA & 0.5
\end{tabular}

${ }^{2} \beta P=\beta$-pinene polymer (Wilt-Pruf ${ }^{\circledR}$; Wilt-Pruf Products, Essex, CT); VP = vinyl-acrylic polymer (Moisturin; WellPlant, Sparks, NV); SACl = sugar alcohol-based compound l (Stasis $;$; Natural Industries, Houston, TX); SAC2 = sugar alcohol-based compound 2 (Root-Zone ${ }^{\text {tw }}$; GSI Horticultural, Bend, OR); s-ABA = biologically active form of abscisic acid (ConTego ${ }^{\mathrm{Tm}}$, VBC-30101; Valent BioSciences, Libertyville, IL).

$1 \mathrm{~mL} \cdot \mathrm{L}^{-1}=1000 \mathrm{ppm}$

determine whether antitranspirants caused any side effect on plants.

Visual observations of wilt status were taken daily. Evaluation of wilt status was started just before the application of antitranspirants. Evaluation continued until all plants reached a visual wilt status rating of 3 or below. The shelf life of waterstressed plants was calculated as the number of days from the initiation of water being withheld until plants reached a wilt status rating of 3 (Waterland et al., 2010c).

EXPT. 2: Wilt STATUS AND STOMATAL CONDUCTANCE OF ANTITRANSPIRANT-TREATED BEDDING PLANTS. Four-week-old seedlings of 'Harmony Spicy Peach' new guinea impatiens were obtained in 72-plug trays from Green Circle Growers Inc. in Apr. 2014. Seeds of 'Antigua Yellow' and 'Taishan Orange' african marigold, and 'Ultra Red' petunia were sowed in a 288-plug tray in Mar. 2014. 'Ultra Red' petunias were used in Expt. 2, because 'Madness Double Red' and 'Wave Pink' petunias used in Expt. 1 were unavailable. All seedlings were transplanted into 4-inch pots in Apr. 2014 and grown in the greenhouse as described previously. Average PPFD was 304 $\mu \mathrm{mol} \cdot \mathrm{m}^{-2} \cdot \mathrm{s}^{-1}$ from 0630 to $2030 \mathrm{HR}$ daily $\left(\right.$ DLI $\left.=15.3 \mathrm{~mol} \cdot \mathrm{m}^{-2} \cdot \mathrm{d}^{-1}\right)$. Average greenhouse temperatures were $23.7 / 18.1 \pm 3.0 / 2.5{ }^{\circ} \mathrm{C}$ day $/$ night (mean $\pm \mathrm{SD}$ ) with daytime relative humidity of $72.6 \% \pm 16.1 \%$. Based on the observations from Expt. 1, one physical $(\beta \mathrm{P})$ and a physiological (s-ABA) antitranspirant were selected for the additional experiment at the recommended rate $(1 \times)$. An additional treatment of 'Antigua Yellow' and 'Taishan Orange' african marigold with $\beta \mathrm{P}$ at $2 \times$ was performed. Antitranspirants were treated to new guinea impatiens and marigold in July 2014 and petunia in Aug. 2014. $\beta$ P was sprayed (about $35 \mathrm{~mL}$ per plant), and $\mathrm{s}-\mathrm{ABA}$ was drenched $(60 \mathrm{~mL}$ per pot). Plants were watered to container capacity $12 \mathrm{~h}$ before application. Control plants and antitranspirant-treated plants were either irrigated or water-stressed as described above. After all water-stressed plants reached a wilt status rating of 3 or below, they were rewatered daily to determine if there was any damage by antitranspirant. Visual wilt status of stressed plants was evaluated as described previously.

Stomatal conductance was measured with a portable photosynthesis system (LI-6400XT; LI-COR, Lincoln, NE). Three fully expanded leaves per plant were tagged for measurements. Stomatal conductance measurements were taken $1 \mathrm{~d}$ before treatment, $4 \mathrm{~h}$ after the treatment, daily until all plants showed visual wilting, and $3 \mathrm{~d}$ after plants were rewatered. A leaf was placed into a light-emitting diode light source chamber (6400-02B, LI-COR). Environmental conditions in the chamber were set at $1000 \mu \mathrm{mol} \cdot \mathrm{m}^{-2} \cdot \mathrm{s}^{-1}$ PPFD, $400 \mu \mathrm{mol} \cdot \mathrm{mol}^{-1}$ carbon dioxide, and $25^{\circ} \mathrm{C}$ as the block temperature. Readings were conducted from 1000 to 1400 Hr. Data are the means of measurements from three replications (or three plants), with three leaves measured per plant $(n=3)$.

STATISTICAL ANALYSIS. Experiments were conducted as a randomized complete block design with three replications $(n=3)$. Analysis of variance was performed by SAS (version 9.3; SAS Institute, Cary, NC). Bedding plants were blocked by replication based on plant position in the greenhouse and watering regimen (irrigated daily vs. water-stressed). Differences among the treatment means were assessed by Tukey's test at $P \leq 0.05$.

\section{Results}

Expt. 1: SHELF LIFE OF ANTITRANSPIRANT-TREATED BEDDING PLANTS. The application of $\beta P$ at manufacturer's recommended rate $(\mathrm{l} \times)$ delayed wilting symptoms in impatiens and two cultivars of african marigold increasing shelf life by 1 to
$1.3 \mathrm{~d}$ as compared with stressed controls, whereas other species of plants did not show any extension of shelf life with $\beta P$ (Table 2). All tested bedding plants showed delayed visible wilting by s-ABA treatment and extended shelf life by 1.3 to $3.7 \mathrm{~d}$ depending on the cultivar (Table 2). In contrast to $\beta P$ or $s$-ABA treatment, shelf life extension was not observed in any species treated with VP or SACs. Among the three rates of application $(0.5 \times, 1 \times$, and $2 \times)$, longer shelf life extension was observed when a higher rate $(2 \times)$ of antitranspirant was applied compared with lower rates $(0.5 \times$ and $1 \times)$ in 'Taishan Orange' african marigold treated with $\beta P$ and 'Wave Pink' petunia treated with s-ABA (Table 3). Impatiens treated with s-ABA had longer shelf life extension at $1 \times$ and $2 \times$ than that at $0.5 \times$ (Table 3 ). All other plant species treated with $\beta \mathrm{P}$ or s-ABA and any of the plants treated with VP or either SACs had no difference in extension of shelf life regardless of application rates (data not shown). Overall, the longest shelf life extension was observed in 'Taishan Orange' african marigold treated with $\beta \mathrm{P}$ at $2 \times$ by $2 \mathrm{~d}$, and in impatiens and new guinea impatiens by almost $4 \mathrm{~d}$ when treated with s-ABA at $2 \times$ and $1 \times$, respectively (Tables 2 and 3 ).

EXPT. 2: Wilt STATUS AND STOMATAL CONDUCTANCE OF ANTITRANSPIRANT-TREATED BEDDING PLANTS. Applications of $\beta \mathrm{P}$ and s-ABA, which showed the extended shelf life in Expt. 1, were performed to examine if there was a relationship between wilt status and $g_{s}$. Two cultivars of african marigold, new guinea impatiens, and 'Ultra Red' petunia were treated with $\beta \mathrm{P}$ and $\mathrm{s}-\mathrm{ABA}$ at the recommended rate $(\mathrm{l} \times)$. Additionally, the application of $\beta \mathrm{P}$ at $2 \times$ was included in both cultivars of african marigold since the longest shelf life was observed at that rate in Expt. 1 (Table 3).

As in Expt. 1, the application of $\beta \mathrm{P}$ delayed wilting symptoms in african marigold, but not in new guinea impatiens and petunia (Fig. 1). 'Antigua Yellow' african marigold treated with $\beta P$ at $1 \times$ and $2 \times$ did not show any visible wilting symptom $2 \mathrm{~d}$ after treatment, whereas stressed control plants had a lower wilt status rating on the same day (Fig. $1 \mathrm{~B}$ ). A different african marigold cultivar, Taishan Orange, treated with the 
Table 2. The number of days until the appearance of wilting symptom in eight bedding plants treated with antitranspirants at manufacturer's recommended rate $(1 \times)$ under water deficit stress.

\begin{tabular}{|c|c|c|c|c|c|c|c|}
\hline \multirow[b]{4}{*}{ Cultivar } & \multicolumn{7}{|c|}{ Type of antitranspirant } \\
\hline & \multicolumn{7}{|c|}{ Time before wilted $(\mathrm{d})^{\mathrm{z}}$} \\
\hline & \multicolumn{3}{|c|}{ Physical $^{y}$} & \multicolumn{4}{|c|}{$\begin{array}{r}\text { Physiological }^{x} \\
\end{array}$} \\
\hline & Control & $\boldsymbol{\beta P}$ & VP & Control & SACI & SAC2 & s-ABA \\
\hline Bada Bing Rose begonia & $8.3 \mathrm{a}^{\mathrm{w}}$ & $8.3 \mathrm{a}$ & $9.0 \mathrm{a}$ & $8.7 \mathrm{~b}$ & $8.0 \mathrm{~b}$ & $8.7 \mathrm{~b}$ & $10.0 \mathrm{a}$ \\
\hline Harmony Spicy Peach new guinea impatiens & $2.0 \mathrm{a}$ & $2.0 \mathrm{a}$ & $2.3 \mathrm{a}$ & $2.0 \mathrm{~b}$ & $2.3 \mathrm{~b}$ & $2.0 \mathrm{~b}$ & $5.7 \mathrm{a}$ \\
\hline Double Fiesta Ole Purple Stripe impatiens & $2.0 \mathrm{~b}$ & $3.0 \mathrm{a}$ & $2.3 \mathrm{ab}$ & $2.3 \mathrm{~b}$ & $2.7 \mathrm{~b}$ & $2.0 \mathrm{~b}$ & $5.3 \mathrm{a}$ \\
\hline Antigua Yellow african marigold & $2.0 \mathrm{~b}$ & $3.3 \mathrm{a}$ & $2.0 \mathrm{~b}$ & $2.3 \mathrm{~b}$ & $2.0 \mathrm{~b}$ & $2.3 \mathrm{~b}$ & $5.3 \mathrm{a}$ \\
\hline Taishan Orange african marigold & $2.0 \mathrm{~b}$ & $3.0 \mathrm{a}$ & $2.3 \mathrm{ab}$ & $2.0 \mathrm{~b}$ & $2.0 \mathrm{~b}$ & $2.0 \mathrm{~b}$ & $5.0 \mathrm{a}$ \\
\hline Bonanza Yellow french marigold & $2.0 \mathrm{a}$ & $2.0 \mathrm{a}$ & $2.0 \mathrm{a}$ & $2.0 \mathrm{~b}$ & $2.0 \mathrm{~b}$ & $2.0 \mathrm{~b}$ & $4.7 \mathrm{a}$ \\
\hline
\end{tabular}

${ }^{2}$ Values are the number of days from the time antitranspirants were applied until plants started showing visible symptoms of wilting. Values are means of three replications $(\mathrm{n}=3)$.

${ }^{y}$ Control $=$ sprayed with deionized $(\mathrm{DI})$ water once on Day 0 and then water was withheld; $\beta \mathrm{P}=\beta$-pinene polymer; VP $=$ vinyl-acrylic polymer.

${ }^{\mathrm{x}} \mathrm{Control}=$ drenched with DI water once on Day 0 and then water was withheld; $\mathrm{SACl}=$ sugar alcohol-based compound $1 ; \mathrm{SAC} 2=$ sugar alcohol-based compound $2 ; \mathrm{s}-\mathrm{ABA}=$ biologically active form of abscisic acid.

"Mean separation among either physical or physiological antitranspirants within cultivars by Tukey's significance test at $P \leq 0.05$.

Table 3. Shelf life extension of two cultivars of african marigold treated with $\beta$-pinene polymer ( $\beta P)$, and impatiens and petunia treated with a biologically active form of abscisic acid (s-ABA) at three rates under water deficit stress.

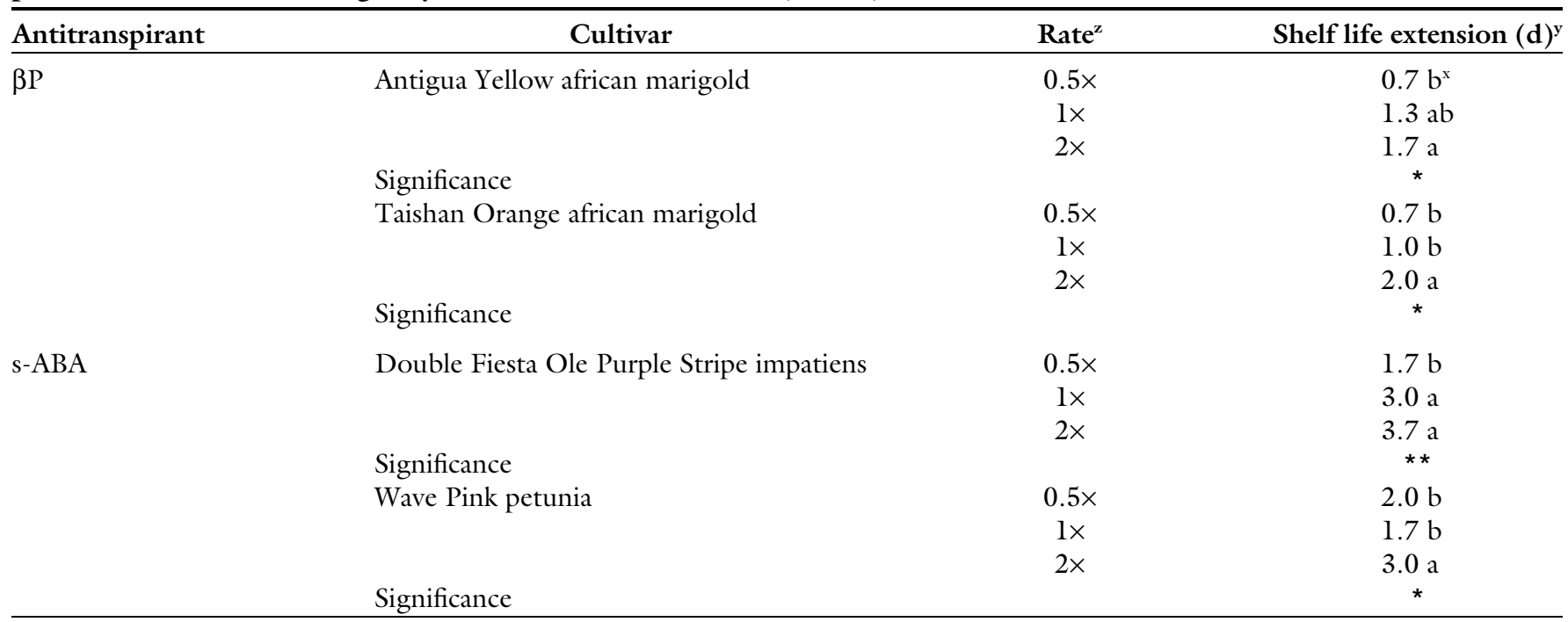

${ }^{\mathrm{z}}$ Half $(0.5 \times)$, equal to $(1 \times)$, or twice $(2 \times)$ the manufacturer's recommended application rate.

Values are the number of additional days from the time when the control plants began to wilt until the time antitranspirant-treated plants started to show visible symptoms of wilting. Values are means of three replications $(n=3)$.

${ }^{x}$ Mean separation among three rates within a cultivar by Tukey's significance test at $P \leq 0.05$.

${ }^{*},{ }^{*}$ Significant at $P \leq 0.05$ or 0.01 , respectively.

higher rate of $\beta P(2 \times)$ showed less visible wilting than stressed control or plants treated with $1 \times$ of $\beta P$ on 2 and $3 \mathrm{~d}$ after treatment (Fig. 1C). Petunia did not show any difference in visual wilting symptoms between stressed control and $\beta \mathrm{P}$-treated plants during the period of water deficit stress (Fig. 1D).

Stomatal conductance decreased $45 \%$ to $73 \%$ compared with that of control plants within $4 \mathrm{~h}$ after treatment with $\beta P$ in both irrigated daily and water-stressed new guinea impatiens and two cultivars of african marigold
(Fig. 1A-C). As water stress progressed, $g_{S}$ of stressed controls declined and their value became similar to that of $\beta \mathrm{P}$-treated plants 4,2 , and $2 \mathrm{~d}$ after treatment in new guinea impatiens, 'Antigua Yellow' african marigold, and 'Taishan Orange' african marigold, respectively (Fig. lA-C). The application of $\beta \mathrm{P}$ reduced $g_{s}$ in water-stressed petunia $4 \mathrm{~h}$ after treatment, but it became similar to control $1 \mathrm{~d}$ after treatment (Fig. 1D). Comparing the application rates of $\beta \mathrm{P}$ in two cultivars of african marigolds, there was no $g_{s}$ difference between plants treated at $2 \times$ and $1 \times$ $4 \mathrm{~h}$ after treatment (Fig. $1 \mathrm{~B}$ and $\mathrm{C}$ ).

All plants treated with s-ABA had delayed visual wilting (Fig. 2) and exhibited a wilt status rating over 4 for $4 \mathrm{~d}$ (new guinea impatiens) and $3 \mathrm{~d}$ (african marigold and petunia) after the application (Fig. 2). Four hours after $\mathrm{s}$-ABA application, reduced gs was observed in all cultivars tested under irrigated daily and water-stressed conditions (Fig. 2). Stomatal conductance of water-stressed control plants reached nearly the same level as s-ABA-treated plants 2 to $4 \mathrm{~d}$ after treatment (Fig. 2). 


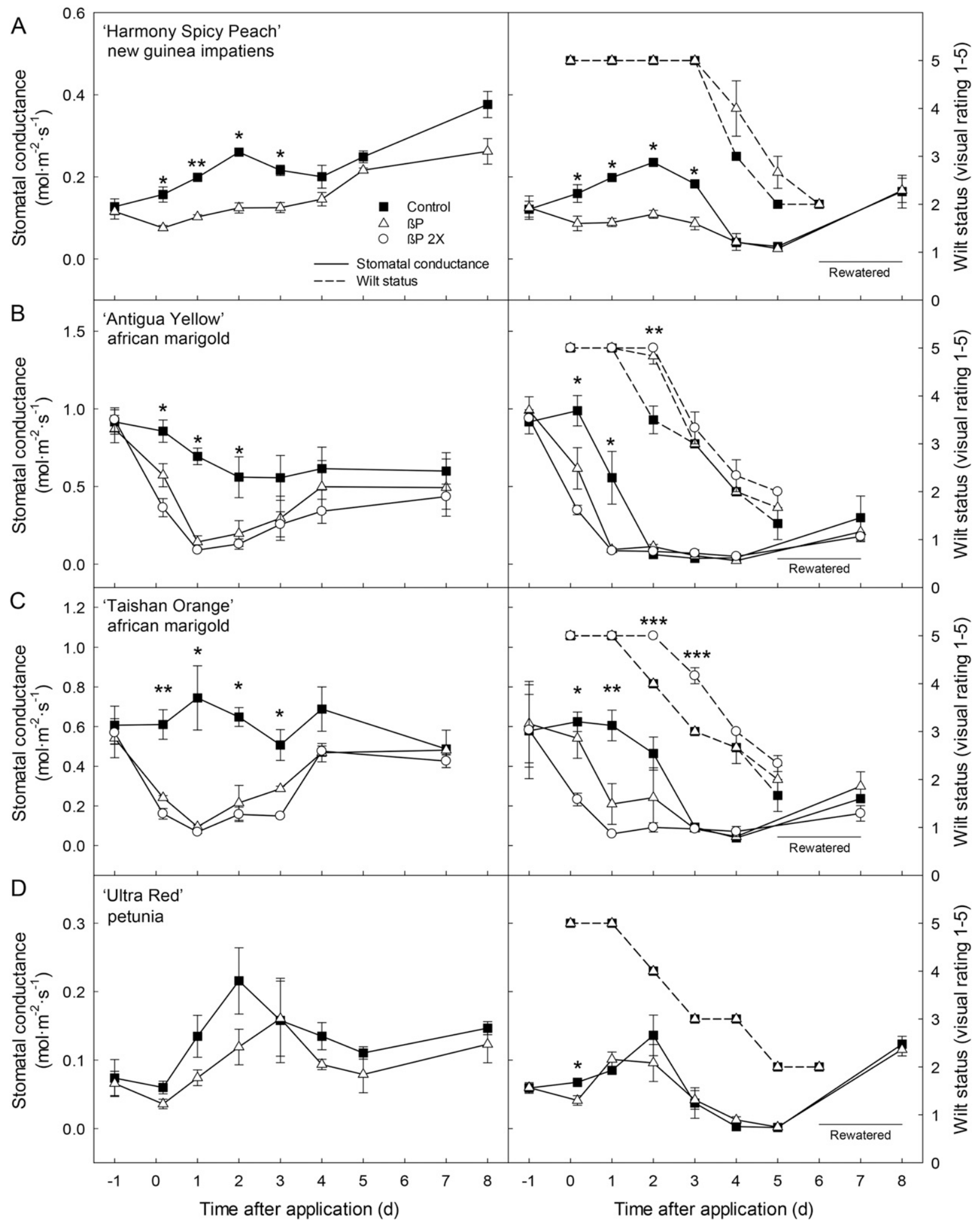

Fig. 1. Stomatal conductance $\left(g_{s}\right)$ and wilt status rating of $\beta$-pinene polymer $(\beta P)$-treated (A) 'Harmony Spicy Peach' new guinea impatiens, (B) 'Antigua Yellow' african marigold, (C) 'Taishan Orange' african marigold, and (D) 'Ultra Red' petunia. $\beta P$ was applied at the manufacturer's recommended rate $(1 \times)$ in all tested cultivars. African marigolds were treated with $\beta P$ at $1 \times$ and $2 \times$. Half of plants were irrigated daily (left), and the other half had water withheld until plants showed wilt status rating of 3 and irrigation was resumed for $3 \mathrm{~d}$ (right). Stomatal conductance was measured $1 \mathrm{~d}$ before the application, $4 \mathrm{~h}$ after the application, daily until all plants showed wilt symptom, and $3 \mathrm{~d}$ after plants were rewatered. Irrigated controls had wilt status of 5 for the duration of the experiment, and water-stressed plants had a rating of 5 after $3 \mathrm{~d}$ rewatering period. Wilt status ratings were from 5 to 1 , where $5=$ completely turgid, $4=$ soft to touch but still upright, $3=$ starting to wilt, $2=$ severely wilted, and 1 = wilted to the point that leaves are desiccated. Vertical bars are standard errors of the means with three replications $(\mathrm{n}=3) .{ }^{*,}{ }^{* *},{ }^{* *}$ Significant at $P \leq 0.05,0.01$, or 0.001 , respectively. 


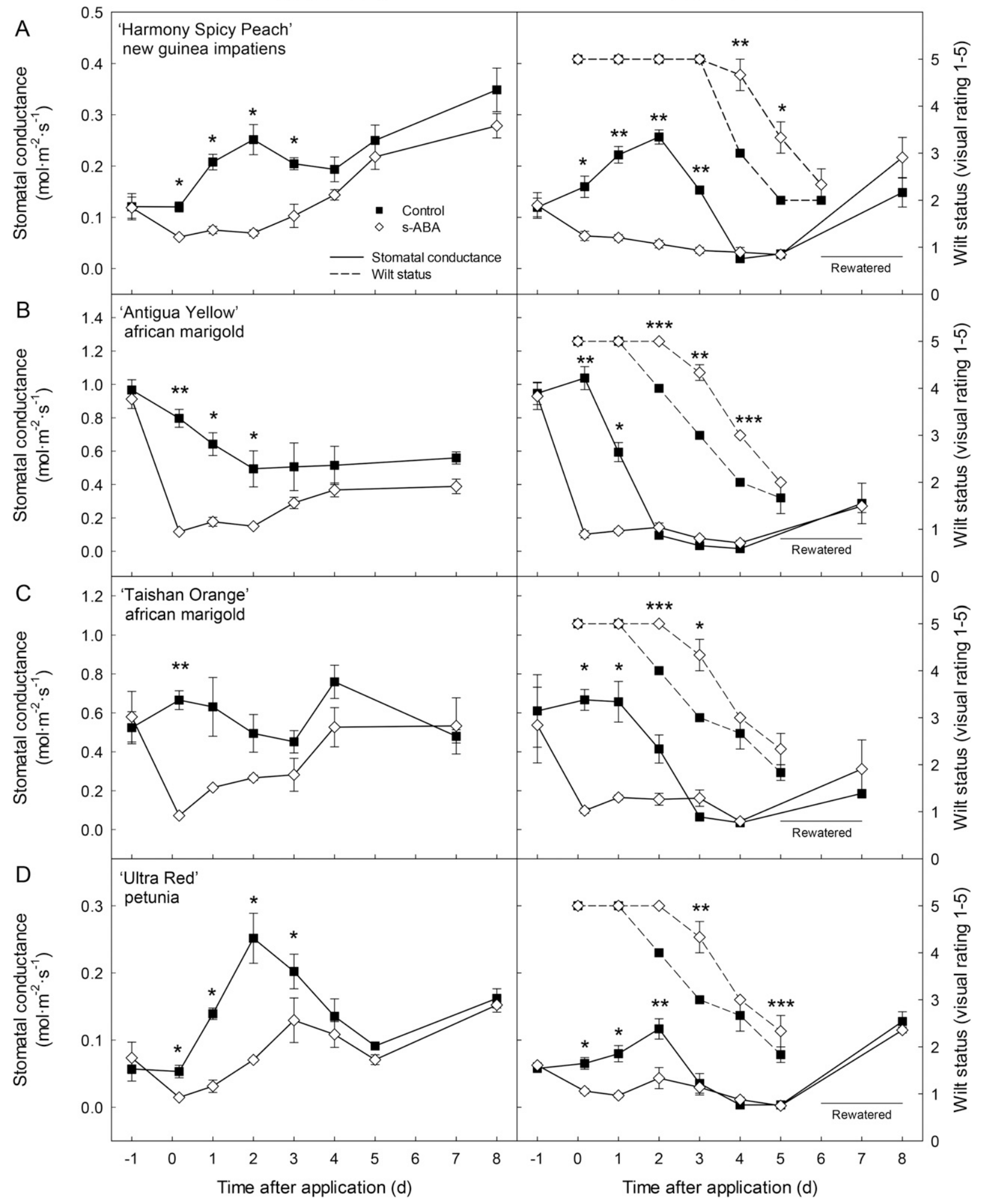

Fig. 2. Stomatal conductance $\left(g_{s}\right)$ and wilt status rating of a biologically active form of abscisic acid (s-ABA)-treated (A) 'Harmony Spicy Peach' new guinea impatiens, (B) 'Antigua Yellow' african marigold, (C) 'Taishan Orange' african marigold, and (D) 'Ultra Red' petunia. s-ABA was applied at the manufacturer's recommended rate $(1 \times)$. Half of plants were irrigated daily (left), and the other half had water withheld until plants showed wilt status rating of 3 and irrigation was resumed for $3 \mathrm{~d}$ (right). Stomatal conductance was measured $1 \mathrm{~d}$ before the application, $4 \mathrm{~h}$ after the application, daily until all plants showed wilt symptom, and $3 \mathrm{~d}$ after plants were rewatered. Irrigated controls had wilt status of 5 for the duration of the experiment, and water-stressed plants had a rating of 5 after $3 \mathrm{~d}$ rewatering period. Wilt status ratings were from 5 to 1 , where $5=$ completely turgid, $4=$ soft to touch but still upright, 3 = starting to wilt, 2 = severely wilted, and 1 = wilted to the point that leaves are desiccated. Vertical bars are standard errors of the means with three replications $(n=3) .{ }^{*},{ }^{* *},{ }^{* *}$ Significant at $P \leq 0.05,0.01$, or 0.001 , respectively. 


\section{Discussion}

Two physical and three physiological antitranspirants were evaluated for enhancing temporary water stress tolerance in eight popular cultivars of bedding plants. Among the five antitranspirants examined, only $\beta \mathrm{P}$ in certain cultivars and s-ABA in all cultivars showed positive effects on enhancing water stress tolerance. Three other antitranspirants (VP and SACs) were not effective and consequently further evaluation of VP and SACs was not performed.

A sharp decline of $g_{s} 4 \mathrm{~h}$ after application of $\beta \mathrm{P}$ and s-ABA compared with controls indicated that application of $\beta P$ effectively blocked stomata or s-ABA induced stomatal closure at the early stage of application in those plants (Figs. 1 and 2). The delay in wilting was likely due to stomatal closure and the subsequent reduction in water loss, thus delaying the loss in leaf turgidity (Figs. 1 and 2 ). A rapid reduction of $g_{s}$ resulting from application of antitranspirants helped to maintain a high water status under water stress and thus improved water stress tolerance (Astacio and van Iersel, 2011; Kim and van Iersel, 2011 ; Shinohara and Leskovar, 2014; Waterland et al., 2010b). Additionally, Anderson and Kreith (1978) reported that $\beta \mathrm{P}$ treatment resulted in initial reduction of transpiration rate by reducing $\mathscr{g}_{s}$ of sweetclover (Melilotus officinalis) leaves. The application of $\beta \mathrm{P}$ caused a reduction in water use of peach trees by $40 \%$ immediately after treatment, with a subsequent decrease in water use by $30 \%$ for the next $30 \mathrm{~d}$ (Steinberg et al., 1990). Although $\beta P$ treatment reduced $g_{s}$ within $4 \mathrm{~h}$ in petunia, transpiration resumed $1 \mathrm{~d}$ after treatment, as indicated by similar $\mathscr{g}_{\mathrm{s}}$ to control, and it did not delay wilting (Fig. 1D). Therefore, the rapid and sustained reduction in $g_{s}$ by antitranspirants before water stress seemed to greatly reduce transpirational water loss during the beginning of water stress period, thus delaying wilting symptoms. As $\beta \mathrm{P}$ - and s-ABA-treated plants were irrigated daily, gs gradually increased to the same level of irrigated controls (Figs. 1 and 2). Thus, the efficacy of antitranspirants was diminished as plants were irrigated or as time passed.

Our findings also support the idea that the effects of $\beta P$ on enhancing water stress tolerance appeared to be species dependent. Application of $\beta \mathrm{P}$ did not extend shelf life universally, but only in impatiens and african marigold, among the six species tested when they were treated at the manufacturer's recommended rate (Table 2). Studies have reported that physical antitranspirants resulted in different responses depending on species (Davies and Kozlowski, 1974; Hummel, 1990). Species differences in response to physical antitranspirants might be associated with differences in shape, size, and density of trichomes (Goreta et al., 2007). Since physical antitranspirants are sprayed on the leaf surface to coat the stomata with a thin film of the chemicals, trichome patterns might affect the chemical's adhesion and retention on leaves differently (Palliotti et al., 2010; Pathan et al., 2009). In artichoke (Cynara cardunculus), physical antitranspirants were not effective to mitigate water stress, presumably due to the dense glandular trichomes (Shinohara and Leskovar, 2014). Indeed, the petunia cultivar evaluated in this research has hirsute leaves, whereas african marigold has rather glabrous leaves. New guinea impatiens tested also have fewer trichomes than petunia and reduced $g_{s}$ was observed when $\beta \mathrm{P}$ was applied (Fig. 1A). The denser trichomes might have prevented $\beta \mathrm{P}$ from forming a thin film layer on the stomata. Species-dependent response to $\beta \mathrm{P}$ in this experiment may have been due to the different characteristics of surface trichome patterns.

Application of s-ABA enhanced water stress tolerance in all plants tested, and the range of extended shelf life varied from 1.3 to $3.7 \mathrm{~d}$ depending on species and cultivars. Responses to ABA treatments have been shown to vary according to species (Blanchard et al., 2007; Waterland et al., 2010a). Blanchard et al. (2007) reported that sprench application of $\mathrm{s}$-ABA at 125 or $250 \mathrm{mg} \cdot \mathrm{L}^{-1}$ delayed wilting by 1.1 to $5.8 \mathrm{~d}$ in 'Harmony Grape' new guinea impatiens, but no significant effect of s-ABA on shelf life was observed in 'Tempo Lavender' impatiens or 'Vabana' bacopa (Sutera cordata). In 'Double Fiesta Ole Purple Stripe' impatiens, application of s-ABA at 250 , 500 , and $1000 \mathrm{mg} \cdot \mathrm{L}^{-1}$ extended the shelf life by 1.7 to $3.7 \mathrm{~d}$ (Table 3 ). Longer shelf life of 'Xtreme Lavender' impatiens either drenched or sprayed with s-ABA was also observed by Waterland et al. (2010a). The differences between previously published reports and the result from our research may be due to different cultivar selection, s-ABA concentration, application method, and environmental conditions.

In contrast to $\beta \mathrm{P}$ and $\mathrm{s}-\mathrm{ABA}, \mathrm{VP}$ and SACs did not exhibit any positive or negative effect on shelf life extension in all eight cultivars at manufacturers' recommended rates (Table 2). VP had shown increased survival rate of green ash [Fraxinus pennsylvanica (Harris and Bassuk, 1995)] and reduced water use in nursery trees (Englert et al., 1993) after transplanting. However, those plants were subjected to water stress by transplanting and might not have experienced similar levels of water stress as in the present study, which withheld water from container-grown plants. Dunn et al. (2012) found that SACs delayed

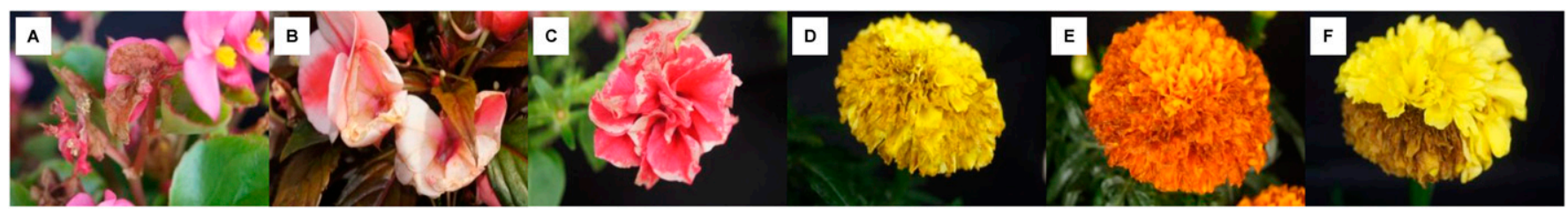

Fig. 3. Floral damage of bedding plants treated with $\beta$-pinene polymer ( $\beta P$ ) at $\mathbf{l} \times$. (A) 'Bada Bing Rose' begonia, (B) 'Harmony Spice Peach' new guinea impatiens, (C) 'Madness Double Red' petunia, (D) 'Antigua Yellow' african marigold, (E) 'Taishan Orange' african marigold, and (F) 'Bonanza Yellow' french marigold. 
the visual wilting rating of herbaceous and woody ornamentals compared with nontreated controls, but in a speciesdependent manner. The authors mentioned that the species-dependent responses might be due to the different application rates, retention, and accumulation of chemicals in soilless media. SACs are expected to lower water potential in growing media to induce water stress. In our research, all plants treated with either SAC showed no delay in wilting symptoms even at twice the recommended rate, indicating that SACs failed to trigger a water stress response.

Although application of $\beta \mathrm{P}$ was effective in certain plant species, $\beta \mathrm{P}$ caused floral damage in all plants tested regardless of application rate (Fig. 3). Floral damage was first observed within a few hours after $\beta P$ treatment, and the floral damage seemed to accelerate flower senescence, resulting in poor quality bedding plants. However, no damage was observed in shoots, flower buds, or leaves. Steinberg et al. (1990) reported that $\beta P$ did not significantly reduce growth or bud and fruit initiation in peach tree. Therefore, application of $\beta \mathrm{P}$ should be recommended before flower opening. On the other hand, s-ABA caused chlorosis on the margin of leaves in impatiens. Foliar chlorosis and leaf abscission have been frequently mentioned as side effects of ABA application (Agehara and Leskovar, 2012; Astacio and van Iersel, 2011; Kim and van Iersel, 2011; Waterland et al., 2010a, 2010c; Weaver and van Iersel, 2014). Chlorosis has been known to accelerate with increasing ABA concentration (Agehara and Leskovar, 2012; Astacio and van Iersel, 2011; Weaver and van Iersel, 2014).

The efficacy of five antitranspirants to increase temporary tolerance to water stress was evaluated in six species of bedding plants. Among five antitranspirants, $\beta \mathrm{P}$ and $\mathrm{s}-\mathrm{ABA}$ treatment enhanced temporary water stress tolerance in severely waterstressed plants by blocking and closing stomata, respectively. This explanation was supported by the observation that $g_{S}$ was quickly decreased on application of either antitranspirant. Consequently, shelf life was increased by 1 to $3.7 \mathrm{~d}$ depending on species and application rates. The application of $\beta \mathrm{P}$ or $\mathrm{s}-\mathrm{ABA}$ as an antitranspirant would allow some bedding plants to withstand temporary water stress during postproduction such as the shipping and retailing environments. However, the efficacy of $\beta P$ appears to be species dependent in our research, possibly due to the difference in trichome patterns of leaf surface. Caution should be applied, given that the application of $\beta P$ and $s-A B A$ could cause floral damage or leaf chlorosis. Floriculture growers should evaluate the effects of antitranspirants on their crops to maximize aesthetic quality and longevity of their products without any side effects.

\section{Literature cited}

Agehara, S. and D.I. Leskovar. 2012. Characterizing concentration effects of exogenous abscisic acid on gas exchange, water relations, and growth of muskmelon seedlings during water stress and rehydration. J. Amer. Soc. Hort. Sci. 137:400-410.

Anderson, J.E. and F. Kreith. 1978. Effects of film-forming and silicone antitranspirants on four herbaceous plant species. Plant Soil 49:161-173.

Astacio, M.G. and M.W. van Iersel. 2011. Determining the effects of abscisic acid drenches on evapotranspiration and leaf gas exchange of tomato. HortScience 46:1512-1517.

Blanchard, M., L. Newton, E. Runkle, D. Woolard, and C. Campbell. 2007. Exogenous applications of abscisic acid improved the postharvest drought tolerance of several annual bedding plants. Acta Hort. 775:127-132.

Davies, W.J. and T.T. Kozlowski. 1974. Short-and long-term effects of antitranspirants on water relations and photosynthesis of woody plants. J. Amer. Soc. Hort. Sci. 99:297-304.

del Amor, F.M., P. Cuadra-Crespo, D.J. Walker, J.M. Cámara, and R. Madrid. 2010. Effect of foliar application of antitranspirant on photosynthesis and water relations of pepper plants under different levels of $\mathrm{CO}_{2}$ and water stress. J. Plant Physiol. 167:1232-1238.

Dunn, B.L., J.C. Cole, and M.E. Payton. 2012. Use of antitranspirants to reduce water stress on herbaceous and woody ornamentals. J. Environ. Hort. 30:137-145.

Englert, J.M., K. Warren, L.H. Fuchigami, and T.H. Chen. 1993. Antidesiccant compounds improve the survival of bareroot deciduous nursery trees. J. Amer. Soc. Hort. Sci. 118:228-235.
Ferrante, A., A. Trivellini, D. Scuderi, D. Romano, and P. Vernieri. 2015. Postproduction physiology and handling of ornamental potted plants. Postharvest Biol. Technol. 100:99-108.

Goreta, S., D.I. Leskovar, and J.L. Jifon. 2007. Gas exchange, water status, and growth of pepper seedlings exposed to transient water deficit stress are differentially altered by antitranspirants. J. Amer. Soc. Hort. Sci. 132:603-610.

Harris, J.R. and N.L. Bassuk. 1995. Effects of defoliation and antitranspirant treatment on transplant response of scarlett oak, green ash and Turkish hazelnut. J. Arboricult. 21:33-36.

Healy, W. 2009. Piles of money. GrowerTalks Mag. 72(12):42-46.

Hummel, R.L. 1990. Water relations of container-grown woody and herbaceous plants following antitranspirant sprays. HortScience 25:772-775.

Iriti, M., V. Picchi, M. Rossoni, S. Gomarasca, N. Ludwig, M. Gargano, and F. Faoro. 2009. Chitosan antitranspirant activity is due to abscisic acid-dependent stomatal closure. Environ. Expt. Bot. 66:493-500.

Kim, J. and M.W. van Iersel. 2011. Abscisic acid drenches can reduce water use and extend shelf life of Salvia splendens. Sci. Hort. 127:420-423.

Odlum, K.D. and S.J. Colombo. 2007. The effect of three film-forming antitranspirants on moisture stress of outplanted black spruce seedlings. Tree Planters' Notes 38:23-26.

Palliotti, A., S. Poni, J. Berrios, and F. Bernizzoni. 2010. Vine performance and grape composition as affected by earlyseason source limitation induced with anti-transpirants in two red Vitis vinifera L. cultivars. Austral. J. Grape Wine Res. $16: 426-433$.

Pathan, A., M. Kimberley, W. Forster, M. Haslett, and K. Steele. 2009. Fractal characterisation of plant canopies and application in spray retention modelling for arable crops and weeds. Weed Res. 49:346-353.

Shinohara, T. and D.I. Leskovar. 2014. Effects of ABA, antitranspirants, heat and drought stress on plant growth, physiology and water status of artichoke transplants. Sci. Hort. 165:225-234.

Steinberg, S.L., M.J. McFarland, and J.W. Worthington. 1990. Antitranspirant reduces water use by peach trees following harvest. J. Amer. Soc. Hort. Sci. 115:20-24.

Taiz, L. and E. Zeiger. 2010. Plant physiology. 5th ed. Sinauer, Sunderland, MA. 


\section{Research Reports}

U.S. Department of Agriculture. 2014. Floriculture crops 2013 summary. U.S. Dept. Agr., Washington, DC.

Waterland, N.L., C.A. Campbell, J.J. Finer, and M.L. Jones. 2010a. Abscisic acid application enhances drought stress tolerance in bedding plants. HortScience 45:409-413.

Waterland, N.L., J.J. Finer, and M.L. Jones. 2010b. Abscisic acid applications decrease stomatal conductance and delay wilting in drought-stressed chrysanthemums. HortTechnology 20:896 901 .

Waterland, N.L., J.J. Finer, and M.L. Jones. 2010c. Benzyladenine and gibberellic acid application prevents abscisic acid-induced leaf chlorosis in pansy and viola. HortScience 45:925-933.
Weaver, G.M. and M.W. van Iersel. 2014. Antitranspirational efficacy and longevity of abscisic acid and a synthetic abscisic acid analog in pansies (Viola ×wittrockiana). HortScience 49:779784.

Yue, C. and B.K. Behe. 2008. Estimating US consumers' choice of floral retail outlets. HortScience 43:764-769. 